\title{
Anatomical, Chemical and Mechanical Characteristics of Beech Wood Degraded by Two Pleurotus Species
}

\section{Anatomska, kemijska i mehanička svojstva bukova drva degradiranoga gljivama roda Pleurotus}

\author{
Original scientific paper • Izvorni znanstveni rad \\ Received-prispjelo: 9. 2. 2019. \\ Accepted-prihvaćeno: 20. 11. 2019. \\ UDK: $630 * 812.71 ; 630 * 844.2$ \\ https://doi.org/10.5552/drvind.2020.1906
}

(C) 2020 by the author(s).

Licensee Faculty of Forestry, University of Zagreb.

This article is an open access article distributed under the terms and conditions of the Creative Commons Attribution (CC BY 4.0) license.

\begin{abstract}
The aim of this study was to determine the destructive capabilities of the two white rot fungi Pleurotus cornucopiae $(P c)$ and $\underline{P \text {. eryngii }}(P e)$ compared with the standard fungus Trametes versicolor $(T v)$ on beech wood samples after 60 days of incubation. Understanding of the white rot decay is important as it is necessary for the development of effective solutions for wood protection. Measurements of mass loss, chemical, mechanical properties and light microscopical investigations were conducted prior to and after incubation. Mass loss of samples was found to be 9-22\% depending on fungi species. Impact bending strength is not as sensitive as presumed in classical literature. Light microscopy analysis revealed that decay patterns were similar for both fungi. Wood cell wall thinning, fungal colonization hyphae were also the same for both fungi. Results indicated considerable wood attack by both Pleurotus species, Pc being more destructive than Pe.
\end{abstract}

Keywords: Pleurotus cornucopiae; Pleurotus eryngii; Trametes versicolor; wood decay; chemical analysis; light microscopy

SAŽETAK • Cilj rada bio je utvrditi učinak dviju gljiva bijele truleži - Pleurotus cornucopiae (Pc) i $\underline{\text { P. eryngii }}$ (Pe) - na uzorcima bukova drva nakon 60 dana inkubacije u usporedbi s učinkom standardne gljive Trametes versicolor (Tv). Razumijevanje degradacije drva zbog bijele truleži iznimno je važno za razvoj učinkovitih rješenja zaštite. U pokusu su prije i nakon inkubacije drva provedena mjerenja gubitka mase, kemijskih i mehaničkih svojstava te je obavljeno ispitivanje svjetlosnim mikroskopom. Utvrđeno je da je gubitak mase uzoraka iznosio $9-22 \%$, ovisno o vrsti gljive. Čvrstoća drva na savijanje nije toliko osjetljiva na utjecaj gljiva kao što se navodi u klasičnoj literaturi. Analiza slika dobivenih svjetlosnim mikroskopom pokazala je da su procesi propadanja drva pri zarazi objema gljivama slični. Stanjivanje stijenki drvnih stanica i hife kolonizacije obiju gljiva također su bile jednake. Rezultati su pokazali znatnu degradaciju drva napadnutoga gljivama roda Pleurotus, s tim da je gljiva Pc destruktivnija od gljive Pe.

Ključne riječi: Pleurotus cornucopiae; Pleurotus eryngii; Trametes versicolor; propadanje drva; kemijska analiza; svjetlosna mikroskopija

${ }^{1}$ Authors are assistant professors at Department of Natural Resources and Earth Science, Shahrekord University, Shahrekord, Iran. 


\section{INTRODUCTION}

\section{UVOD}

Wood is one of the most important building materials. It has been used for various applications such as construction, furniture, poles, and sports equipment. However, non-durable and susceptible wood species are prone to fungal degradation. Degradation develops if the moisture content of wood exceeds certain limit, which is associated to fiber saturation point (Schmidt 2006). Wood-decaying fungi play a prominent number of ecological roles in forest ecosystems that affect the health, diversity, productivity, and development of their biotic communities such as mycorrhizal associations with vascular plants, pathogens of commercial tree species, decomposers of coarse organic material, and food resources for wildlife (Marcot, 2017).

There are various classifications of wood degrading fungi, and the most important is based on the color of degraded wood; white-, brown-, and soft-rot, bluestain and sap-stain fungi (Zink and Feng, 1989; Schmidt, 2006). The white-rot fungi predominatly associated with hardwood wood species, where two degradation patterns are described, namely, selective and non-selective white rot as described by Eriksson et al. (1990). The selective fungi degrade and consume predominately hemicellulose and lignin, while the nonselective white rot fungi, beside hemicellulose and lignin, degrades cellulose as well (Eriksson et al., 1990; Zabel and Morrell, 1992; Eaton and Hale, 1993; Schwarze et al. 2004; Schmidt, 2006; Bari et al., 2019). In the nature, different fungal species colonize a variety of substrates. Some fungi are more specialized than the others (Bari et al., 2019). In this regards, Pleurotus species are reported as one of the most important and robust white rot fungi. For example, in the Northern forests of Iran, a colony of them can be found on beech, hornbeam, oak, and aspen wood, clearly proving their flexibility (Ershad, 2009).

Most of forests in Iran are located in the northern parts, bordering the coastal plain at the Caspian Sea and on the northern slopes of the Alborz Mountain range. These forests cover an area $850 \mathrm{~km}$ long and vary in width from 20 to $70 \mathrm{~km}$. The forests of this region are known as Hyrcanian forests. These Hyrcanian forests comprise a little more than 1.9 million ha of almost $100 \%$ hardwoods, mainly beech (Fagus orientalis) and hornbeam (Carpinus betulus) (Kiaei and Samariha, 2001). Pleurotus genus is one of the most important basidiomycetes from commercial perspective, due to their gastronomic, nutritional and medicinal properties. Another factor that contributes to their commercial importance is the fact that they can be easily cultivated on a wide range of substrates, from straw to wood (Solár et al., 2007; Aghajani et al., 2018; Humar, 2013) Preferential degradation of wheat straw lignin was studied by Martinez et al. (1994), who concluded that Pleurotus eryngii and P. ostreatus are the most promising fungi. They reported that $P$. eryngii was the most successful organism examined, exhibiting nearly $50 \%$ reduction of Klason lignin during a solid-state fermentation (SSF) experiment.
Beech wood is an important wood species, but unfortunately it is very susceptible to fungal degradation; hence it was used in the respective study. The objectives of the present study were to screen the capabilities and decay patterns of the two Pleurotus species, $P$. cornucopiae and $P$. erygii, by applying them on beech wood samples and determine the biological, chemical, and mechanical properties of decayed wood as well as compare their degradation capacities to standard white-rot fungus Treametes versicolor. These data are important because of constructional and biotechnological reasons. Degraded wood can be used in various fermentation processes from biogas to bioethanol production (Taherzadeh et al., 2008).

\section{MATERIALS AND METHODS} 2. MATERIJALI I METODE

\subsection{Fungi}

2.1. Gljive

Fruiting bodies of Pleurotus cornucopiae (Paulet) Rolland (Pc) and Pleurotus eryngii (De) Quél. (Pe) were collected from living beech trees (Fagus orientalis Lipsky.) at Hezarjarib forests, (located in Neka, Iran) during the spring 2017. Macro- and microscopic identification was carried out in accordance with the keys of Eriksson and Ryvarden (1975), Gilbertson and Ryvarden (1986), Ryvarden (1991), Ryvarden and Gilbertson (1993).

\subsection{Wood samples}

\subsection{Uzorci drva}

Wood blocks were obtained from (Fagus orientalis) trees at breast height and air-dried to reach $23 \pm 2$ $\%$ moisture content. Specimens of $(5 \times 2.5 \times 1.5) \mathrm{cm}^{3}$ according to the EN113 standard (1997) were used for the determination of mass loss (ML), and $(6 \times 5 \times 0.6)$ $\mathrm{cm}^{3}$ according to ASTM-D256-04 standard (ASTM 2004) for testing impact bending strength. The specimens used to evaluate impact bending strength were cut in cross section. Ten replicate specimens were prepared from different disks for each test. They were kept in a conditioning chamber $\left(25^{\circ} \mathrm{C}\right.$, and $\left.40 \pm 3 \% \mathrm{RH}\right)$ for 4 weeks before testing.

\subsection{Mass loss after biological test}

\subsection{Gubitak mase nakon biološkog testa}

In order to evaluate the degradation capabilities of the Pleurotus species, beech wood samples were oven dried at $103 \pm 3{ }^{\circ} \mathrm{C}$ for $24 \mathrm{~h}$ and weighed prior to fungal exposure. Wood blocks were sterilized at $121^{\circ} \mathrm{C}$ for $20 \mathrm{~min}$ and exposed to fungi according to EN113. Fungi were incubated for 60 days at $22 \pm 2{ }^{\circ} \mathrm{C}$ and relative humidity of $65 \pm 5 \%$. Ten replicates were used for each treatment. After exposure, surface mycelium was scraped off and wood samples were weighed before drying at $103{ }^{\circ} \mathrm{C}$ for $24 \mathrm{~h}$ to determine the final moisture content $(M C)$. After drying, the mass loss $(M L)$ was obtained (Eq. 1 and 2).

$$
M C(\%)=\frac{M_{\mathrm{w}}-M_{\mathrm{d}}}{M_{\mathrm{d}}} \times 100
$$




$$
M L(\%)=\frac{M_{\mathrm{i}}-M_{\mathrm{d}}}{M_{\mathrm{i}}} \times 100
$$

Where $M C$ is moisture content $(\%), M L$ is mass loss $(\%), M_{\mathrm{i}}$ dry mass before decay $(\mathrm{g}), M_{\mathrm{w}}$ wet mass after decay $(\mathrm{g}), M_{\mathrm{d}}$ dry mass after decay $(\mathrm{g})$.

\subsection{Chemical analyses}

2.4. Kemijska analiza

Changes in the chemical constituents of the wood cell walls of sound wood controls and samples, following exposure to fungi, were evaluated according to TAPPI standards test methods. The Klason lignin was determined according to T-222 om-98 of TAPPI standard. Oven-dried, extractive-free sawdust $(1 \mathrm{~g})$ was mixed with $15 \mathrm{ml}$ of $72 \%$ sulfuric acid for $2 \mathrm{~h}$ at room temperature. The mixture was diluted with $560 \mathrm{ml}$ of distilled water, heated for $4 \mathrm{~h}$, and the insoluble materials were filtered off. The residue was washed and dried at $103{ }^{\circ} \mathrm{C}$. The lignin content was calculated using Eq. (3)

$$
K L(\%)=\frac{S_{\mathrm{d}}-K L}{S_{\mathrm{d}}} \times 100
$$

Where $S_{\mathrm{d}}$ is the dried weight of sawdust and $K L$ is the dried weight of extracted Klason lignin.

Cellulose content was determined in accordance with T-17 wd-70 of TAPP; $2 \mathrm{~g}$ of sawdust (free from extractives) were mixed with $96 \%$ EtOH $(100 \mathrm{ml})$ and $65 \%$ nitric acid $(50 \mathrm{ml})$. The mixture was heated under reflux for $1 \mathrm{~h}$, cooled and filtered. The residue was washed with distilled water and dried at $103{ }^{\circ} \mathrm{C}$. Cellulose content was then calculated by Eq. (4):

$$
\text { Cellulose }(\%)=\frac{S_{\mathrm{d}}-E C}{S_{\mathrm{d}}} \times 100
$$

Where $S_{\mathrm{d}}$ is the dried weight of sawdust and $E C$ is the dried weight of extracted cellulose.

\subsection{Impact bending strength}

\subsection{Savojna žilavost}

Impact bending strength was performed according to ASTM-D256-04 and calculated using Equation 3. Before the Impact bending strength test, all samples were conditioned in a standard climate at $20^{\circ} \mathrm{C}$ and 65 $\%$ relative humidity until constant mass was achieved.

$$
I=\frac{F_{\max }}{A}
$$

Where $I$ is resistance to impact $\left(\mathrm{J} / \mathrm{m}^{2}\right), F_{\text {max }}$ is force $(\mathrm{J})$ and $A$ is cross section area $\left(\mathrm{m}^{2}\right)$.

\subsection{Light microscopy}

\subsection{Svjetlosna mikroskopija}

In order to monitor wood degradation, a GSL-1 sliding microtome (WSL, Switzerland) was used to cut thin wood sections $(10-15 \mu \mathrm{m})$ of the blocks $\left(20_{1} \times 10_{\mathrm{r}} \times 8\right.$, $\left.\mathrm{mm}^{3}\right)$. The sections were stained with safranin $(0.5 \%$ aqueous), Astra Blue (0.3\% aqueous) solution and mixed in a 1:1 ratio, washed in distilled water for $1-3$ min and dehydrated by an alcohol series. After rinsing in xylol for 1-2 min, sections were mounted in Mountalan glue (Kimianovin, Tehran, Iran) on microscope slides. To avoid buckling of the sample, a $50 \mathrm{~g}$ weight was placed on the cover glass edges while the slide was drying at $60{ }^{\circ} \mathrm{C}$ for $12 \mathrm{~h}$. Dried sections were examined and photographed with an Olympus E-210 microscope and with an Olympus E-450 camera.

\subsection{Statistical analyses}

2.7. Statistička analiza

Comparison between mass loss and changes in chemical components of the wood was carried out using a Student t-test for each exposure period $(95 \%$ level of confidence). Two-way ANOVA was conducted to examine the effect of decay condition on mass and chemical losses. All statistical analyses were performed using the SPSS software program, version 23.

\section{RESULTS AND DISCUSSION 3. REZULTATI I RASPRAVA}

\subsection{Mass loss}

\subsection{Gubitak mase}

Wood density is one of the first and elementary information. The average dry density of beech wood was $0.63 \mathrm{~g} \cdot \mathrm{cm}^{-3}$. The ring width was between 2.80 and $3.40 \mathrm{~mm}$. Mass loss $(M L)$ of beech wood samples exposed to the fungi after incubation is shown in Figure 1. Average mass losses were $17.40 \%, 8.70 \%$, and $21.76 \%$ after 60 days incubation for P. cornucopiae (Pc), P. eryngii $(\mathrm{Pe})$ and $T$. versicolor $(\mathrm{Tv})$, respectively. The results indicated that Pe were more effective than Pc. However, Tv caused most $M L$. The minimum $M L$ of $20 \%$ by TV is necessary for beech wood after 16 weeks (112 days) of incubation in accordance with EN-113 (1997). On the other hand, the average $M L$ was $20 \%$ and $40 \%$, respectively, in size of $30 \times 10 \times 5 \mathrm{~mm}$ after 12 weeks of exposure (Bravery, 1978). Bari et al. (2019) showed that Pleurotus ostreatus and Tv produced the same $M L$ in beech wood after 120 days of incubation.

\subsection{Moisture content after decay}

3.2. Sadržaj vode nakon razgradnje drva

The moisture content $(M C)$ of wood blocks after fungal incubation is shown in Figure 2. Generally, the $M C$ was $77.09 \%, 65.80 \%$, and $108.51 \%$ after 60 days of incubation for $\mathrm{Pe}, \mathrm{Pc}$ and $\mathrm{Tv}$, respectively. Since fungi need moisture for their enzymes to cleave the cell wall components (Baldrian, 2008), the water is necessary for their function. According to Figure 2, the results demonstrated that the $M C$ of the decayed wood blocks increased with the mass losses caused by both decay fungi. The increase of the mass loss could increase the moisture content in wood blocks. Similar works (Bami and Mohebby, 2011) showed that whiterot fungi caused high water content in decayed wood samples.

\subsection{Cell wall components analysis}

3.3. Analiza dijelova stanične stijenke

Average lignin and cellulose contents of sound and decayed beech wood samples, after 60 days of degradation by fungi, is shown in Figure 3. The graph indicates that the three white-rot fungi severely degraded cellulose and lignin. With regard to lignin, average degradation by fungi was $16.73 \%, 16.63 \%$, and 13.67 $\%$ after 60 days of incubation for Pe, Pc, and Tv, re- 


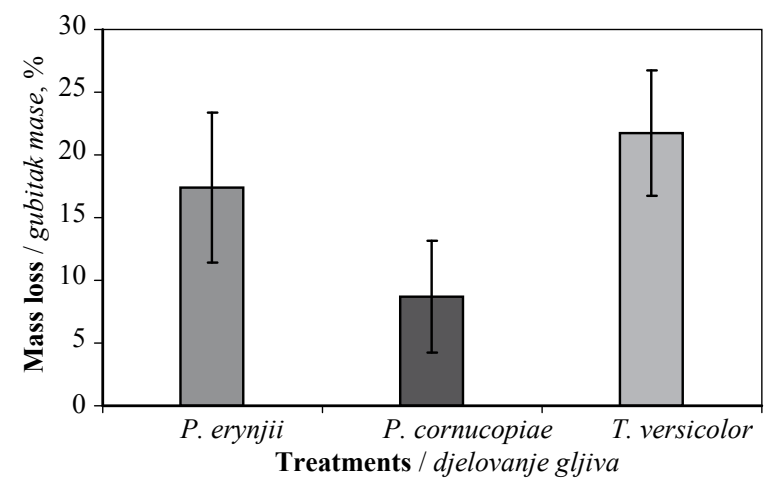

Figure 1 Average percent mass loss of beech wood samples decayed by white rot fungi after 60 days of incubation Slika 1. Prosječni postotni gubitak mase uzoraka bukovine zbog djelovanja gljiva bijele truleži nakon 60 dana inkubacije

spectively, while for the sound wood it was $23.63 \%$. According to Koshijima and Watanabe (2003) and Schmidt (2006), white-rot fungi are the most efficient lignin degraders in nature and they play a key role in carbon recycling on Earth. They break-down the lignin units by secretion of different enzymes to reach the necessary carbon. Average degradation of cellulose by fungi was $32.77 \%, 34.53 \%$, and $28.64 \%$ for Pe, Pc and $\mathrm{Tv}$, respectively. Cellulose is the main carbon source for fungi, especially basidiomycetes (Schmidt, 2006). White rot fungi are divided in selective and simultaneous white-rot species (e.g. Eriksson et al. 1990; Schmidt, 2006). Figure 3 shows that the three fungi caused simultaneous white-rot in beech wood samples. Karim et al. (2016) showed that Pleurotus ostreatus decomposed beech and oak wood samples in natural and controlled conditions also follow a similar lignin degradation pattern. However, indications of selective digestion were also found in some wood cells. However, several researchers (e.g. Martinez et al. 2001, 2005) reported that many Pleurotus species caused the selective rot pattern. Cellulose, lignin content of decayed wood samples in the present study, is much

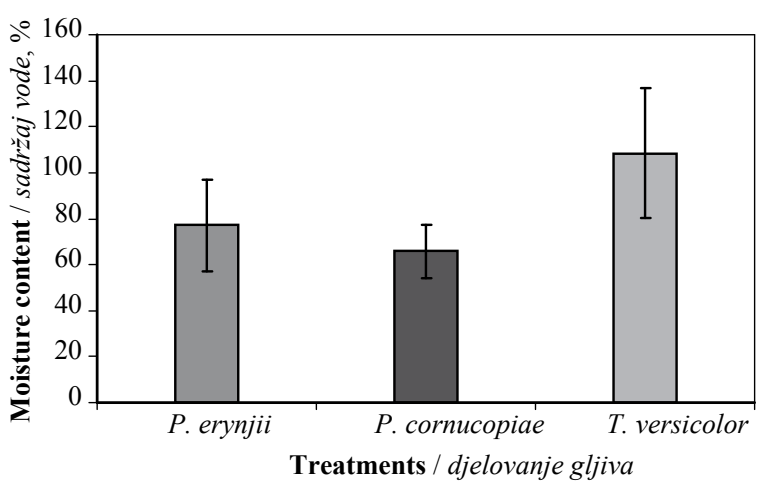

Figure 2 Moisture content of beech wood samples due to fungal metabolism after 60 days of incubation

Slika 2. Sadržaj vode u uzorcima bukovine zbog metabolizma gljiva nakon 60 dana inkubacije

lower than reported by Chen et al. (2017) and Hosseinihashemi et al. (2017). Olfat (2014) indicated that the mass loss of beech wood was $47.5 \%$ after 16 weeks and $13.2 \%$ after 10 weeks. Mass loss values of this study are comparable with the values given by Witomski et al. (2012).

\subsection{Monitoring beech wood degraded by white-rot fungus}

3.4. Praćenje uzoraka bukovine degradiranih djelovanjem gljiva bijele truleži

Wood density is one of the first and basic information. The average density of beech wood is $0.63 \mathrm{~g}$. $\mathrm{cm}^{-3}$. Growth rings are distinct because of the unusually light color of latewood. Two forms of degradation for white rot were described in this study. It is known that $P$. eryngii $(\mathrm{Pe})$ and $P$. cornucopiae $(\mathrm{Pc})$ caused selective lignin degradation. In the selective delignification type, lignin is degraded earlier than cellulose or hemicellulose in the process of decay. During the initial stages of decay, the cellulose is left unchanged during delignification. In some cases, hyphae in the cell lumen grow, so that lignin is separated from the adjacent cell wall (Anagnost, 1998; Schwarze, 2007). In

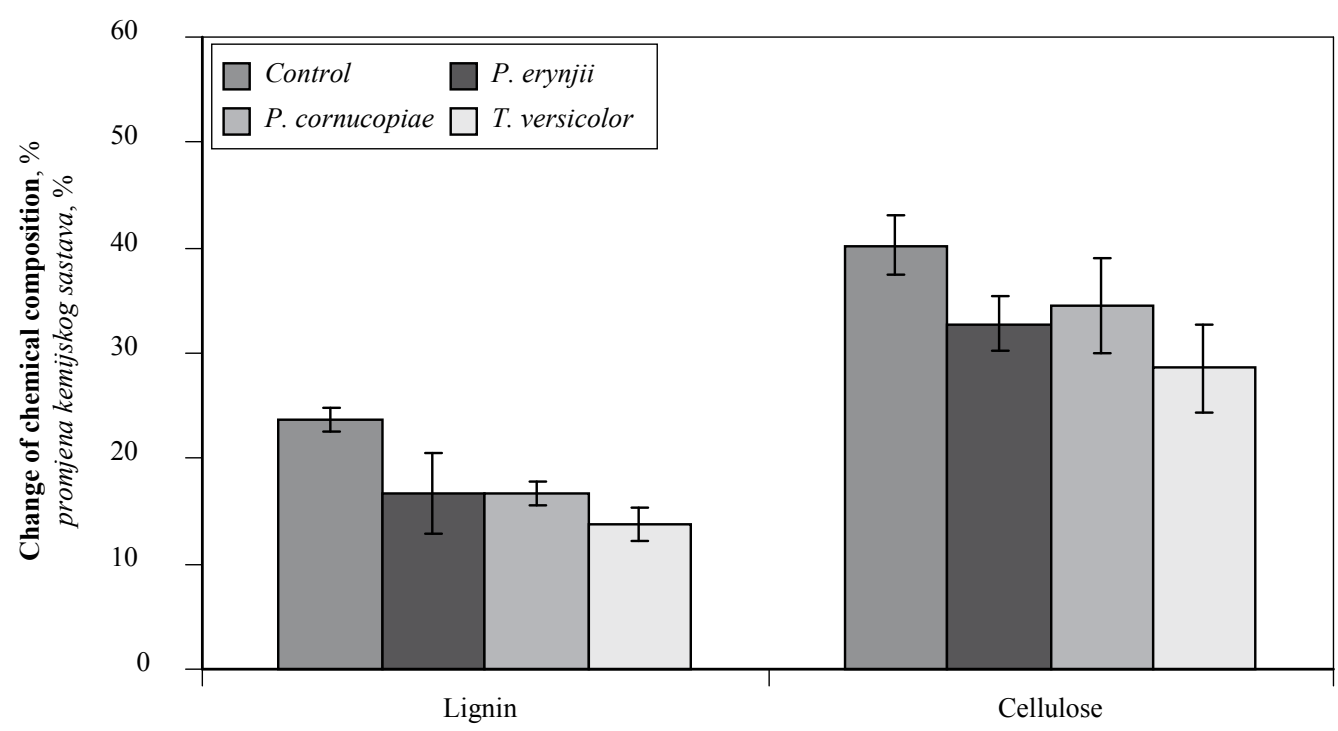

Figure 3 Average percentage of chemical composition in decayed beech wood samples after 60 days of incubation Slika 3. Prosječni postotak promjene kemijskog sastava u uzorcima bukovine djelovanjem gljiva nakon 60 dana inkubacije 

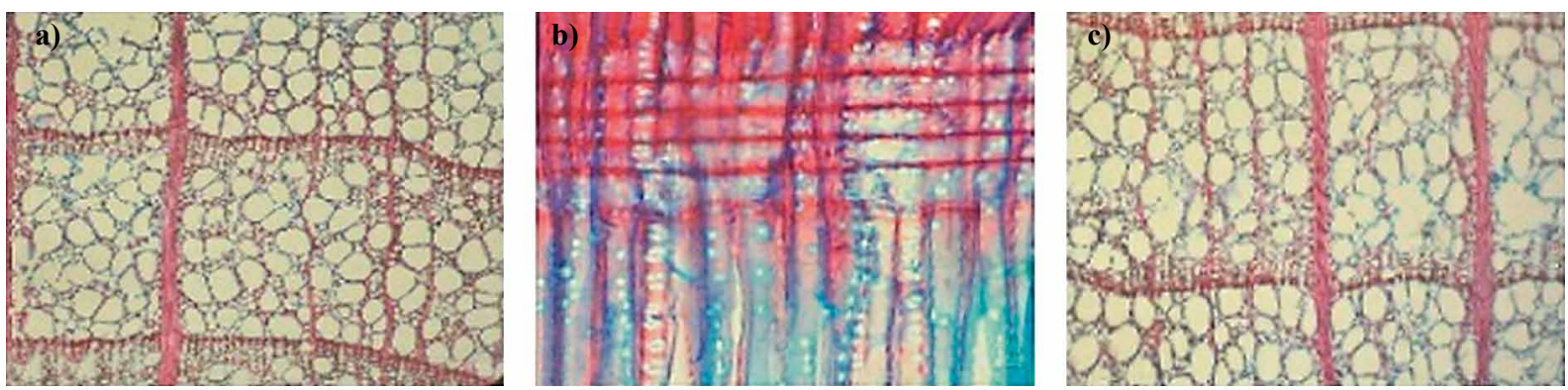

Figure 4 Light micrographs of beech wood degradation after 60 days of exposure to white-rot fungi; (a) Transverse section of beech wood incubated with $P$. eryngii (Pe). (b) Radial longitudinal section of beech wood incubated with $P$. cornucopiae (Pc) (c) Transverse section of beech wood incubated with T. versicolor (Tv)

Slika 4. Svjetlosne mikrografije degradacije uzoraka bukovine nakon 60 dana izlaganja gljivama bijele truleži: a) poprečni presjek uzorka bukovine inkubiranoga gljivom $P$. eryngii (Pe), b) radijalni uzdužni presjek uzorka bukovine inkubiranoga gljivom P. cornucopiae $(\mathrm{Pc})$, c) poprečni presjek uzorka bukovine inkubiranoga gljivom T. versicolor $(\mathrm{Tv})$

the tangent section, the beech wood incubated with $P$. eryngii, as seen in Figure 4a. The hyphae, growing in the cell lumen of the fiber-tracheids, are seen in the early stages of delignification in the secondary walls. As seen in the radial section, the beech wood incubated with $P$. cornucopiae, the hyphae penetrate into the cell walls, and then first separate the middle lamella, so that the cells tend to separate from each other (Tuar et al. 1995; Seshikala and Charya1, 2012). Cellulose is relatively unchanged during selective delignation, at least in the early stages of decay (Figure 4b). T. versicolor cause simultaneous white rot in angiosperms, but only rarely in gymnospermous wood. In many studies, it was reported that this type of white decay degrades the adjacent cell wall for hyphae growing in contact with the lumen surface (Anagnost 1998; Schwarze 2007; Karim et al. 2017; Silva-Castro et al. 2018). The enzymes of $T$. versicolor cause the degradation in all the components of the lignified cell wall. The decomposition of cellulose, hemicellulose and lignin occurs at almost the same rate. As erosion proceedes on the lumen surface, the cell wall becomes thin evenly, as opposed to forming channels (Anagnost, 1998; Schwarze,
2007). This degradation form of $T$. versicolor in beech wood is characterized in Figure 4c. In the transverse sections, advanced thinning resulted in the localized removal of the cell wall and middle lamella.

\subsection{Mechanical evaluation}

3.5. Ocjena mehaničkih svojstava

Figure 5 shows the effects of the cell wall degradation on the impact bending strength after exposure to the white-rot fungi. The average decrease of impact bending strength by the fungi was $3.32 \%, 3.68 \%$, and 3.17 for Pe, Pc, and Tv, respectively, while it was 4.59 $\%$ for the control sample. Overall, both fungi showed a similar effect on the reduction of impact strength. Toughness or impact strength is the ability of wood to absorb the force of impact bending and characterizes the ability of material to withstand impact loads. Impact strength is expressed as the energy consumed while breaking wood with defined dimensions. This mechanical property is most sensitive to decay and, unlike other strength properties that decrease gradually as decay progresses, impact strength declines rapidly during incipient wood decay (Rowell, 2005).

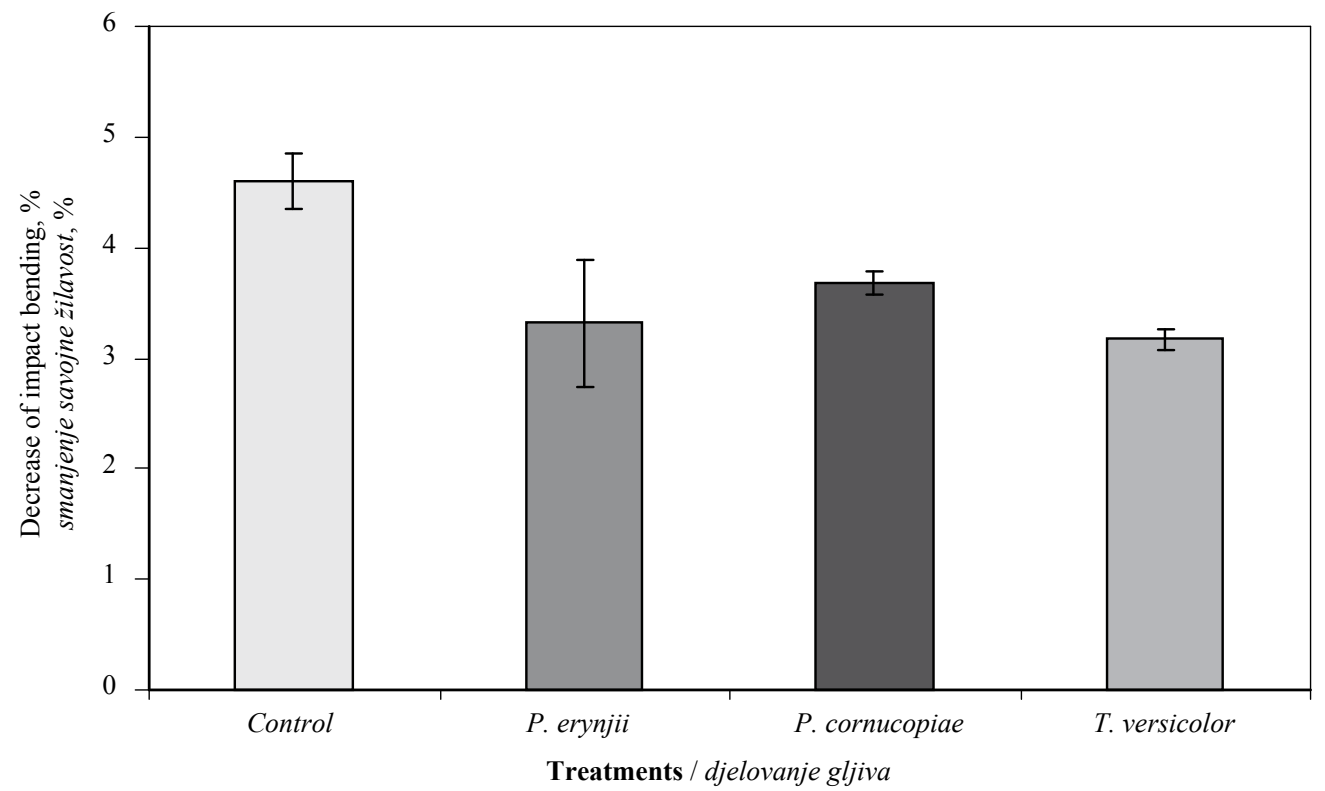

Figure 5 Average percentage of impact bending strength in decayed beech wood samples after 60 days of incubation Slika 5. Prosječni postotak smanjenja savojne žilavosti degradiranih uzoraka bukovine nakon 60 dana inkubacije 
Pleurotus erynjii

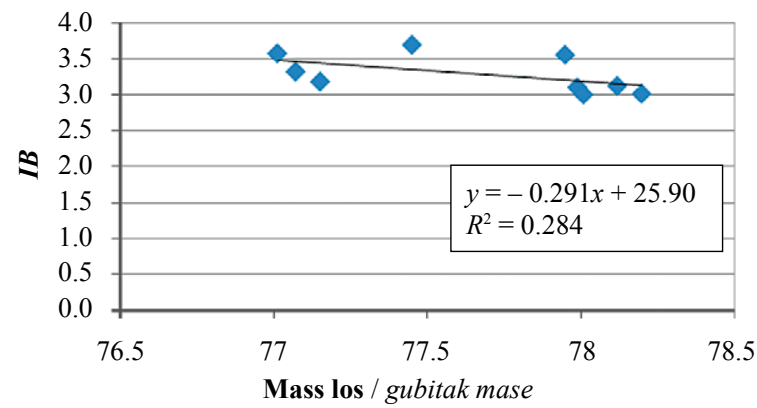

Pleurotus sapidus

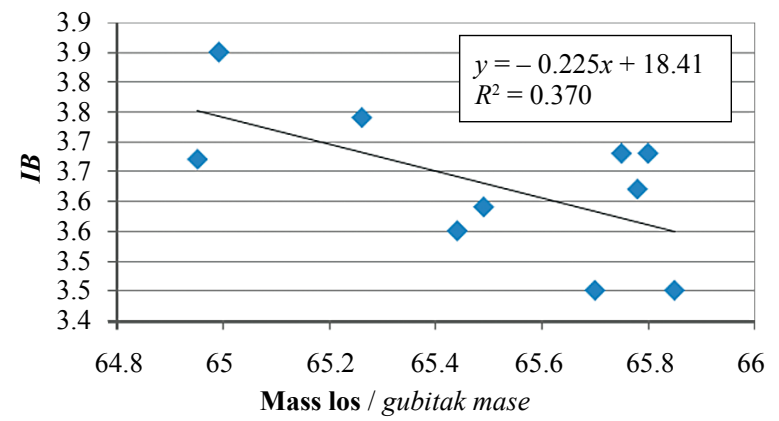

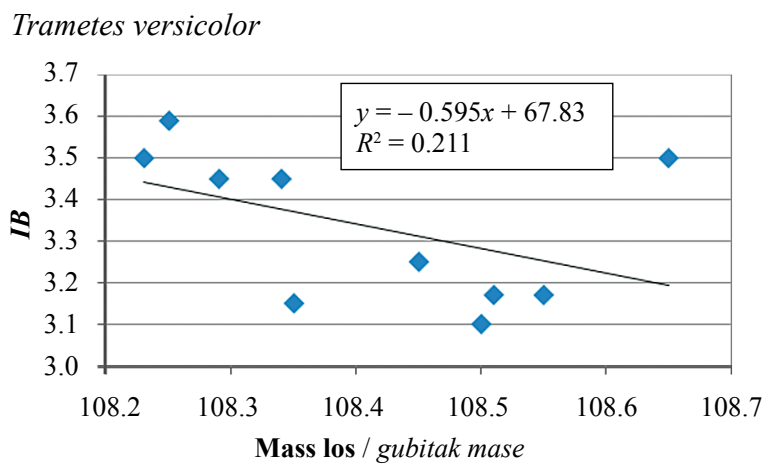

Figure 6 Relationship between mass loss and impact bending strength

Slika 6. Odnos između gubitka mase i savojne žilavosti uzoraka bukovine

Figures 6 shows the correlation between mass loss and impact bending strength data. As can be seen in these figures, the correlation is not very tight.

\section{CONCLUSION \\ 4. ZAKLJUČAK}

Anatomical, chemical and mechanical properties were investigated of beech wood exposed to the two white-rot fungi for 60 days of incubation. The fungus clearly caused simultaneous decay pattern of cell wall polymers in the wood. Results indicated that both Pleurotus species created a considerable mass loss, which was accompanied by losses in chemical and mechanical properties. Altogether, under the conditions of the present research, it was concluded that the decay capacity of $P$. eryngii was more aggressive than that of $P$. cornucopiae in some test cases. According to the obtained results of the present study, the capability of wood rotting fungi for biotechnological applications such as biopulping, bioremediation, biochelation and recycling of treated wood is indisputable. However, their advantages and disadvantages should be considered before attempting industrial-scale operations.

\section{REFERENCES}

5. LITERATURA

1. Anagnost, S. E., 1998: Light microscopic diagnosis of wood decay. IAWA Journal, Vol. 19 (2): 141-167.

2. Baldrian, P., 2008: Enzymes of saprotrophic basidiomycetes. In British mycological society symposia series, 28 : 19-41. Academic Press.

https://doi.org/10.1016/S0275-0287(08)80004-5.
3. Bami, L. K.; Mohebby, B., 2011: Bioresistance of poplar wood compressed by combined hydro-thermo-mechanical wood modification (CHTM): Soft rot and brown-rot. International Biodeterioration \& Biodegradation 65: 866-870. https://doi.org/10.1016/j.ibiod.2011.03.011.

4. Bari, E.; Aghajani, H.; Ohno, K. M.; Shahi, R.; Hale, M. D.; Bahmani, M., 2019: Ecology of wood-inhabiting fungi in northern forests of Iran. Forest Pathology, 49 (2), p.e12501.

5. Bari, E.; Daryaei, M. G.; Karim, M.; Bahmani, M.; Schmidt, O.; Woodward, S.; Ghanbary, M. A.; Sistani, A., 2019: Decay of Carpinus betulus wood by Trametes versicolor-An anatomical and chemical study. International Biodeterioration \& Biodegradation. 137: 68-77. https://doi.org/10.1016/j.ibiod.2018.11.011.

6. Bravery, A. F., 1978: Screening techniques for potential wood preservative chemicals. IRG/WP 2113.

7. Eaton, R. A.; Hale, M. D. C., 1993: Wood: decay, pests and protection. Chapman and Hall, London.

8. Eriksson, J.; Ryvarden, L., 1975: The Corticiaceae of North Europe Volume Coronicium-Hyphoderma, 3, 287-546.

9. Eriksson, K., E.; Blanchette, R.; Ander, P., 1990: Microbial and enzymatic degradation of wood and wood components. Berlin, Germany. https://doi.org/ 10.1007/978-3-642-46687-8.

10. Ershad, D., 2009: Fungi of Iran. Iranian Research Institute of Plant Protection, Tehran, Iran.

11. Gilbertson, R. L.; Ryvarden, L., 1986: North American polypores. Vol. I. Abortiporus-Lindtneria. Oslo, Norway: Fungiflora.

12. Hosseinihashemi, S. K.; Hassani, S.; Latibari, A. J.; Özbay, G., 2017: Chemical Characterization of Bio-oil from Pyrolysis of Undecayed and Decayed Fagus orientalis Wood. Drvna industrija, 68 (2): 113-119. https://doi.org/10.5552/drind.2017.1626.

13. Humar, M., 2013: Influence of Norway spruce and European larch heartwood ring-width on extractive content and durability. Drvna industrija, 64 (2): 79-85. 
14. Karim, M.; Daryaei, M. G., Torkaman, J.; Oladi, R.; Ghanbary, M. A.; Bari, E., 2016: In vivo investigation of chemical alteration in oak wood decayed by Pleurotus ostreatus. International Biodeterioration \& Biodegradation, 108: 127-132. https://doi.org/10.1016/j.ibiod.2015.12.012.

15. Kiaei, M.; Samariha, A., 2011: Relationship between altitude index and wood properties of Pinus eldarica Medw. Gazi University Journal of Science, 24 (4): 911-918.

16. Koshijima, T.; Watanabe, T., 2003: Association between lignin and carbohydrates in wood and other plant tissues. Springer: Berlin - Heidelberg - New York.

17. Marcot, B. G., 2017: A review of the role of fungi in wood decay of forest ecosystems. Res. Note. PNWRN-575. Portland, OR: US Department of Agriculture, Forest Service, Pacific Northwest Research Station, 31 p., 575, pp.1-31.

18. Martínez, A. T.; Camarero, S.; Guillén, F.; Gutiérrez, A.; Muñoz, C.; Varela, E.; Martínez, M. J.; Barrasa, J.; Ruel, K.; Pelayo, J., 1994: Progress in biopulping of nonwoody materials: Chemical, enzymatic and ultrastructural aspects of wheat straw delignification with ligninolytic fungi from the genus Pleurotus. FEMS Microbiology Reviews, 13 (2-3): 265-273. https://doi.org/10.1111/j.1574-6976.1994.tb00047.x.

19. Martínez, A. T.; Camarero, S.; Gutiérrez, A.; Bocchini, P.; Galletti, G. C., 2001: Studies on wheat lignin degradation by Pleurotus species using analytical pyrolysis. Journal of Analytical and Applied pyrolysis, 58-59: 401411. https://doi.org/10.1016/S0165-2370(00)00116-9.

20. Martínez, Á. T.; Speranza, M.; Ruiz-Dueñas, F. J.; Ferreira, P.; Camarero, S.; Guillén, F.; Martínez, M. J.; Gutiérrez Suárez, A.; Río Andrade, J. C., 2005: Biodegradation of lignocellulosics: microbial, chemical, and enzymatic aspects of the fungal attack of lignin. Int Microbiol., 8 (3): 195-204.

21. Mohebby, B., 2003: Biological attack of acetylated wood. Ph.D. thesis. Göttingen University, Germany, $147 \mathrm{pp}$.

22. Olfat, A. M., 2014: Natural durability ratings in Fagus orientalis degraded by wood-rotting Basidiomycetes, Coriolus versicolor. Advances in Environmental Biology, 8 (4): 985-989.

23. Ryvarden, L., 1991: Genera of polypores: Nomenclature and taxonomy. Synopsis Fungorum, 5: 1-373.

24. Ryvarden, L.; Gilbertson, R. L., 1993: European polypores. Part 1. Oslo, Norway: Fungiflora.

25. Schmidt, O., 2006: Wood and Tree Fungi: Biology, Damage, Protection, and Use. Springer- Verlag, Germany.

26. Schmidt, O.; Gaiser, O.; Dujesiefken, D., 2012: Molecular identification of decay fungi in the wood of urban trees. European Journal of Forest Research, 131: 885891. https://doi.org/10.1007/s10342-011-0562-9.

27. Schwarze, F. W., 2007: Wood decay under the microscope. Fungal biology reviews, 21 (4): 133-170. https://doi.org/10.1016/j.fbr.2007.09.001.

28. Schwarze, F. W. M. R.; Engels, J.; Mattheck, C., 2004: Fungal Strategies of Wood Decay in Trees, $2^{\text {nd }}$ ed. Springer-Verlag, New York.
39. Schweingruber, F. H.; Börner, A.; Schulze, E. D., 2011: Atlas of stem anatomy in herbs, shrubs and trees. Springer Science \& Business Media.

30. Seshikala, D.; Charya, M. S., 2012: Collection and screening of Basidiomycetes for better lignin degraders. International Journal of Life Sciences Biotechnology and Pharma Research, 4 (1): 203-211.

31. Silva-Castro, I.; Casados-Sanz, M.; Alonso-Cortés, A.; Martín-Ramos, P.; Martín-Gil, J.; Acuña-Rello, L., 2018: Chitosan-Based Coatings to Prevent the Decay of Populus spp. Wood Caused by Trametes Versicolor. Coatings, 8: 415. https://doi.org/10.3390/coatings8120415.

32. Solár, R.; Kurjatko, S.; Mamoń, M.; Košíková, B.; Neuschlová, E.; Výbohová, E.; Hudec, J., 2007: Selected properties of beech wood degraded by brown-rot fungus Coniophora puteana. Drvna industrija, 58 (1): 3-11.

33. Taherzadeh, M. J.; Karami, K., 2008: Pretreatment of lignocellulosic wastes to improve ethanol and biogas production: a review. International Journal of Molecular Sciences, 9 (9): 1621-1651. https://doi.org/10.3390/ijms9091621.

34. Tuor, U.; Winterhalter, K.; Fiechter, A., 1995: Enzymes of white-rot fungi involved in lignin degradation and ecological determinants for wood decay. Journal of Biotechnology, 41 (1): 1-7. https://doi.org/10.1016/0168-1656(95)00042-O.

35. Witomski, P.; Zawadzki, J.; Radomski, A., 2012: Changes of the pine wood (Pinus sylvestris L.) chemical composition during white-and brown-rot decay originated from chosen fungi species. Wood Research, 57 (3): 463468.

36. Zabel, R. A.; Morrell, J. J., 1992: Wood microbiology. Academic Press, New York.

37. Zink, P.; Fengel, D., 1989: Studies on the coloring matter of blue-stain fungi. Holzforschung 43: 371-374.

38. ***ASTM D256e4, 2004: Standard Methods for Testing Determining the Izod Pendulum Impact Resistance of Plastics.

39. ***EN 113, 1997: Wood preservatives-test method for determining the protective effectiveness against wood destroying basidiomycetes. Determination of toxic values.

40. ***Tappi standard, 1997: T 17. wd-97, Cellulose in wood.

41. ***Tappi standard, 1998: T-222. om-98, Standard methods for acid-insoluble lignin in wood and pulp.

\section{Corresponding address:}

\section{Assist. Prof. MOHSEN BAHMANI}

Faculty of Natural Resources and Earth Sciences Shahrekord University

IRAN

e-mail: mohsen.bahmani@sku.ac.ir 